Helen Makogon ${ }^{1}$, Elya Slavutskyi ${ }^{1}$, Mykyta Churbanov ${ }^{1}$, Oleh Logvinenko $^{1}$, Viktoriia Iksarytsa ${ }^{2}$, Olena Anenkova ${ }^{2}$

${ }^{1}$ Military Institute of Tank Troops of National Technical University, Kharkiv, Ukraine

${ }^{2}$ State boarding school with enhanced military and physical training "Cadet Corps" Kharkiv, Ukraine

\title{
DYNAMIC MONITORING OF TECHNICAL CONDITION OF STARTER BATTERIES IN THE PROCESS OF THEIR LIFE CYCLE ACCORDING TO BATTERY CARE AND BATTERY MANAGEMENT PROCEDURES
}

\begin{abstract}
The subject matter of the article is the lead-acid batteries carrier and management. The goal of the study is to develop a methodology for the technical condition monitoring of starter batteries in the process of their life cycle based on the use of modern information technology. The tasks to be solved are: to carry out a comparative analysis of Battery Care and Battery Management procedures and to determine the technical condition of starter batteries used on native wheeled and tracked vehicles, and to determine the key characteristics of battery monitoring during their life cycle; to determine the method of GB diagnostics for the implementation of dynamic monitoring of its technical condition during the life cycle in accordance with the procedures for battery care and management; to determine the general view of the functional diagram of the battery tracker - a software and hardware device capable of caring for the battery and managing it; to provide suggestions for improving the efficiency of battery maintenance using battery trackers. General scientific and special methods of scientific knowledge are used. The following results are obtained. The suggested methodology makes it easy to determine, by comparing the data obtained at different times, in which batteries the degradation has just begun, and in which they have reached the level at which they need to be replaced without a fatal malfunction. Monitoring of the technical condition of the batteries using battery trackers implement the procedure for care and management of batteries, makes it possible to optimize the 12ST-85P battery maintenance schedule and come from the scheduled-interval maintenance system to the maintenance with parameter control. Conclusions. The development of battery trackers, hardware and software applications capable of battery care and battery management, can be seen as a promising area for the development of battery management. Proper care of the battery and charging equipment, proper operation and timely monitoring of the battery's lifetime are the most important factors in its operation. Only in this case, it is possible to achieve the best economic efficiency of the GB use and prolong their lifetime. Battery Care and Battery Management by the means of a GB-tracker allows to optimize the maintenance schedule of the 12ST-85P batteries and to come from a planned preventive maintenance system to a parameter-controlled maintenance system. In this way it is possible to increase the period and reduce the number of operations to be carried out during the maintenance of the GB.
\end{abstract}

Keywords: Battery Care and Battery Management, a GB-tracker, the lead-acid batteries, the 12ST-85P battery maintenance

\section{Introduction}

Formulation of the problem and research tasks. Battery Care and Battery Management procedures offer experience in monitoring the technical condition of starter batteries in the global automotive industry. The introduction of similar procedures in the operation of starter batteries used in domestic wheeled and tracked vehicles will provide an opportunity to optimize the schedule of their maintenance (MA) and move from the planned warning system to maintenance on demand with control parameters by obtaining operational and reliable information about the current state of GB. Battery Care can be understood as a set of measures that allows you to take care of the battery with the help of special devices, tools, software, etc. Battery Management can be understood as a set of measures that allows you to control the operation of the battery with the help of special devices, tools, software, etc.

The relevance of the study is due to the fact that the procedure for determining the technical condition of starter batteries used in domestic wheeled and tracked vehicles is similar to Battery Management and Battery Status control, but the procedure itself is ineffective in modern conditions and has a number of shortcomings that lead to excessive cost of human and material resources and significant underutilization of battery life.
In this regard, there is a need to develop batterypowered trackers - hardware and software devices capable of caring for and managing starter batteries.

Analysis of recent research and publications of recent research and publications on the above issues shows that the known methods of the GB operational assessment are based on the characteristics obtained by indirect measurements. The basis of such methods are special devices - GB analyzers. The principle of their operation is based on measuring the parameters of the battery (usually internal resistance) on alternating current for 10-20 seconds. The values of the measured parameters allow to estimate the degree of degradation of the battery and to predict the values of the reserve and nominal capacity, the current of the starter discharge GB. Existing methods of monitoring the technical condition of batteries are characterized by long duration, the negative impact of deep discharge, as well as significant energy and human costs $[1,2]$.

Express-diagnosis allows to reduce these shortcomings to a minimum and is based on the mathematical description of GB by means of parameters, proceeding from their properties [3-6]. Of course, the effectiveness of such measures will increase significantly with the use of modern information technology, electronic measuring devices, development of dynamic interfaces, creation of databases, etc. 
The goal of the study is to develop a methodology for the technical condition monitoring of starter batteries in the process of their life cycle based on the use of modern information technology.

This goal defined the following research tasks:

- to carry out a comparative analysis of Battery Care and Battery Management procedures and to determine the technical condition of starter batteries used on native wheeled and tracked vehicles, and to determine the key characteristics of battery monitoring during their life cycle;

- to determine the method of GB diagnostics for the implementation of dynamic monitoring of its technical condition during the life cycle in accordance with the procedures for battery care and management;

- to determine the general view of the functional diagram of the battery tracker - a software and hardware device capable of caring for the battery and managing it; to provide suggestions for improving the efficiency of battery maintenance using battery trackers.

General scientific and special methods of scientific knowledge are used.

\section{Main material}

1. Characteristics for monitoring of batteries during their life cycle. Service life of the batteries under the current system of diagnosis and maintenance is limited and achievable only with strict adherence to the frequency and full implementation of the amount of installed works. Extension of service life of batteries is possible both through the introduction of new equipment for their diagnostics and through selection of a rational scope of work and their frequency of maintenance. Currently available technology maintenance of batteries in their operation allows monitoring the battery parameters for dynamic calculation of their service life (Table 1).

Table 1 - The GB diagnostic parameters for dynamic calculation of their service life

\begin{tabular}{|l|l|c|c|}
\hline № & \multicolumn{1}{|c|}{ Name } & Designation & $\begin{array}{c}\text { Units of } \\
\text { measurement }\end{array}$ \\
\hline 1 & self-discharge & & \\
\hline 2 & Electromotive force & $\varepsilon$ & B \\
\hline 3 & Voltage & U & B \\
\hline 4 & Electrolyte density & & \\
\hline 5 & Charging current & I & A \\
\hline
\end{tabular}

As we can see, the current set of diagnostic parameters is such, which provides indirect information about the capacity, which is considered as the main indicator of the service life of the battery. For dynamic calculation of service life and optimum maintenance terms the collection of such parameters requires great hourly costs, in particular the discharge jet, the discharge current $I_{d}$; during the discharge period $t_{p}[7,8]$.

Influence of temperature $(T)$ and pressure is automatically taken into account when calculating total charge capacity $(C)$ and surplus capacity $\left(C_{f}\right)$. According to the analogy described in the article, $Q_{\max }$ is also calculated and determined when the battery is in use. According to the world experience in the operation of batteries the determination of their technical condition is similar to the procedures of Battery Management and Battery Status control, so the authors are encouraged to introduce such generalized technical condition of batteries used by the military.

$\mathrm{SOH}$ (State of Health) is defined as the state of health of the battery, which reflects the current condition of the battery in comparison with the ideal one.

SOC (State of Charge) is defined as the state of charge of the battery, which shows how much of the total charge is still stored in the battery.

$S O C$ and $\mathrm{SOH}$ monitoring of the lead-acid battery using such a device will ensure the battery charge level monitoring, as well as provide a warning about the need to replace the battery.

The value of the battery charge level tends to decrease when the battery is used longer [9]. However, these data are not identical to the values for GB "health". This leads to the conclusion about the relevance and feasibility of the conducted research.

It is interesting to note that instead of the term "electromotive force" (EMF) it is accepted to use the term "the voltage of an open circle". The literal translation of the phrase "Open-circuit voltage (OCV)" corresponds to the physical essence of the electromotive force. Monitoring of such important GB parameters as impedance, depth of discharge, residual capacity, etc. can also be considered promising. Newly available at .

Passed Charge - integrated charge of the pulse indicator while the battery is being charged or discharged

$S O C$ - state of charge at any time, defined as

$$
S O C=\frac{Q}{Q \max },
$$

here $Q$ - the transferred charge from the state of full charge;

$D O D$ - depth of discharge;

$$
D O D=1-S O C,
$$

$D O D_{0}$ - last $D O D$ reading before charge or discharge;

$D O D_{\text {charge }}-D O D$ for a fully charged battery;

$Q_{\text {start }}$ - charge required for $D O D=D O D_{0}$;

$Q_{\max }$ - maximum chemical capacity of the battery;

$R M$ - residual power;

$F C C$ - full charge power, the amount of charge transferred from a fully charged state.

2. Methods of GB diagnosing for dynamic monitoring of its technical condition during the life cycle according to the procedures for Battery care and management

Let's illustrate the algorithm for determining the SOC and SOH of the 12ST-85P battery. Many diagnostic parameters are determined based on the need for analytical calculations. The authors analyzed the world experience on this issue, so it is further proposed to use the accepted international terms with the indication of known analogues.

Thus, the charge state (SOC) of a lead-acid battery, expressed in $\%$, is the ratio of the remaining capacity $C_{r}$ $(R C)$ to the actual (useful) capacity $C_{f}(F C C)$ : 


$$
S o C=\frac{R C}{F C C}=\frac{C_{r}}{C_{a}},[\%],
$$

here $R C$ (remaining capacity) - residual capacity $C_{r}$, $F C C$ (full charge capacity) - actual (useful) capacity $C_{a}$ at the present charge or discharge rate and temperature;

$\mathrm{SOH}$ controls this chemical degradation and is determined as a percentage $(\%)$ or fraction:

$$
\mathrm{SoH}=\frac{F C C H}{C_{n}}=\frac{C_{a}^{25}}{C_{n}},
$$

here $F C C H$ is the $F C C$ at $25^{\circ} \mathrm{C}$ for design charge or discharge rate.

Thus, if an $G B$ with a design capacity of $85 \mathrm{~A} \mathrm{~h}$ has a $F C C H$ of only $68 \mathrm{~A} \mathrm{~h}$ after one year of operation, its $\mathrm{SOH}$ is $80 \%$.

Thus, the SOC determines how much charge is left before the need for maintenance and charging, while the $\mathrm{SOH}$ indicates when the battery will need to be replaced.

$\mathrm{C}_{\mathrm{f}}$ (FCC) comes from the total chemical capacity of the battery $C_{\max }\left(\mathrm{Q}_{\mathrm{MAX}}\right)$ and battery impedance $\left(\mathrm{R}_{\mathrm{b}}\right)$.

For example, for a new GB with a nominal capacity of $C n=85 \mathrm{~A} \mathrm{~h}$, when it is fully charged, the SOC is $100 \%$, because $F C C(\mathrm{C} f)$ is $85 \mathrm{~A}$ h, and $C r(\mathrm{RC})$ is also $85 \mathrm{~A} \mathrm{~h}$.

If this battery is discharged so that the $C_{r}(R C)$ is $68 \mathrm{~A} \mathrm{~h}$, its $S O C$ will be $80 \%$.

In the process of charge or discharge of the GB is "transfer" of capacity. . Therefore, it is proposed to introduce the concept of passed capacity $C_{p}\left(Q_{\text {passed }},\right)$ ie the capacity given or received by the $C_{p}=\left|\varepsilon_{1}-\varepsilon_{2}\right|$.

B during discharge / charge, respectively. It is logical to assume that. As the battery ages, its total chemical capacity $C_{\max }\left(Q_{\max }\right)$ is usually lower than the design (nominal) capacity due to chemical degradation. $\mathrm{C}_{\mathrm{MAX}}$ is estimated when the battery is at rest (for example, before commissioning) and is calculated by calculating the results of two EMF measurements $\varepsilon_{1}$ and $\varepsilon_{2}$ performed at rest.

Formally, the state of "rest" of the battery can be expressed by the condition that the speed of its discharge / charge $\frac{d V}{d t}$ does not exceed the given one, where $V(t)$ is the value of the voltage GB in time. For example, for $\mathrm{AB} 12 \mathrm{ST}-85 \mathrm{P}$ it is expedient to set a condition $\frac{d V}{d t} \leq 20 \frac{\mu V}{s e c}$. In the laboratory, the state of "rest" of the AB reaches in a few hours.

Then

$$
\begin{aligned}
& S o C_{1}=\frac{\varepsilon_{1}}{C_{\max }} ; \\
& S o C_{2}=\frac{\varepsilon_{2}}{C_{\max }} .
\end{aligned}
$$

From expressions, (4) and (5) follows the value of $C_{\max }$ :

$$
C_{\max }=\frac{\left|\varepsilon_{1}-\varepsilon_{2}\right|}{\left|S o C_{1}-S o C_{2}\right|}
$$

The corresponding ratio in this case is:

$$
C_{M A X}=\frac{C_{P A S E D}}{S O C_{1}-S O C_{2}},
$$

here $C_{P A S S E D}$ - is the charge passed between $S O C_{1}$ and $S O C_{2} ; S O C_{1}-$ is the $S O C$ batteries at rest before charging / discharging; $S O C_{2}-$ is the $S O C$ of the recovered battery after charging / discharging (Fig. 1).

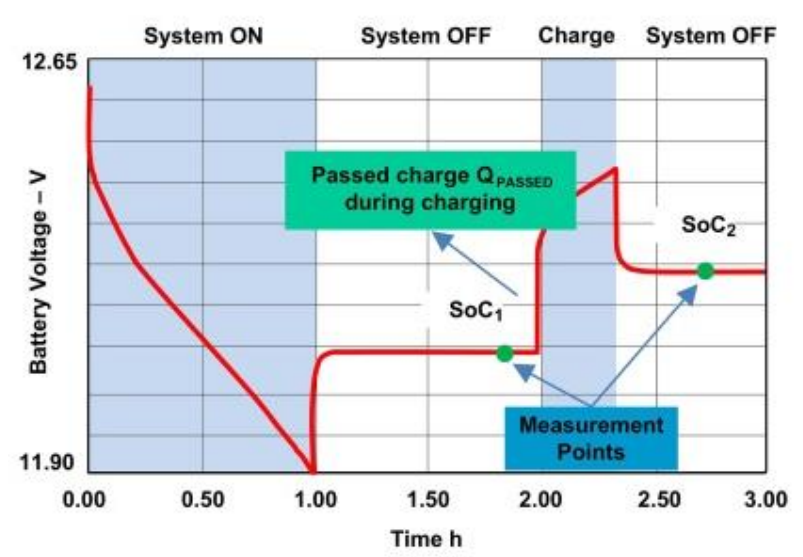

Fig. 1. SoC GB measurements

Then, the transferred capacity will be related to the maximum capacity ratio

$$
C_{\text {MAX }}=\frac{C_{n}}{S o C_{1}-S o C_{2}},
$$

here $C_{P}-$ transferred capacity will be understood as the capacity measured between the "rest" of the battery before the transfer of capacity.

Thus, using expression (8) it is possible to obtain the state of the battery without conducting a full cycle of its discharge / charge.

Before use, when the battery is at rest and the current is below the threshold selected by the consumer, the $S O C$ is determined using the measured voltage and a predefined table of $E M F$ to $S O C$ ratios, taking into account the temperature compensation. These data are unique to this type of battery and chemical composition. During charging and discharging, SOC is constantly calculated using $C$ and $C_{f}$ according to recurrent dependencies, and $\mathrm{SOH}$ is calculated using $\mathrm{C}^{25}$ and design capacity.

$S O C$ and $\mathrm{SOH}$ calculations depend on an accurate estimate of $C$ and internal resistance. $R_{i n}$. We will add that at carrying out diagnostics by alternating current which is widely applied in modern automobile devices of express diagnostics, analogy of Rin is considered impedance of the $R_{B A T}$ battery. When applying an external load, the impedance can be calculated measured according to Ohm's law for a full circuit by finding the difference between the measured voltage under load and the EMF, specific to the present current state of charge $S O C$ and taking into account the GB temperature.

After calculating $C_{M A X}$, the same value is used to calculate $\mathrm{SOC}$ and $\mathrm{SOH}$ during charging / discharging until the next $C_{M A X}$ update is performed. Similarly, $R_{B A T}$ is estimated by the equation: 


$$
R_{B A T}=\frac{U-\varepsilon}{I},
$$

here $\mathrm{U}-$ is the battery voltage; $\varepsilon$ - electromotive force; $I$ - charge / discharge current.

Battery voltage is measured constantly, even in the absence of load. Continuous voltage measurement is used to update information about the current state of charge. Then, when the load is applied, the method of calculation determines the resulting charge passing through the system "GB - tracker"." in the forward or reverse direction. After removing the load, the batteries are given some time to recover, and the voltage is measured again.

Using the data of two voltage measurements and the results of calculating the total charge, you can determine the maximum battery capacity. You can also calculate the current impedance based on the measured current, no-load voltage with corrections for temperature and charge status. Note that the term "available capacity" is defined as the capacity that the GB has in the current conditions. The actual capacity is determined on a fully charged battery at a constant temperature $T=25 \pm 2{ }^{\circ} \mathrm{C}$. Under such conditions, the ratio $S_{d}=S_{f}$. In other conditions, the actual capacity will be the calculated value of $k \mathrm{~S}_{\mathrm{d}}$ ( $\mathrm{k}$ is the coefficient that takes into account the change in the capacity of the GB depending on the temperature) $[10,11]$.

3. Functional diagram of the battery tracker - a software and hardware device capable of caring for and managing the battery. As a prototype of the chip for the software implementation of monitoring procedures Battery Care and Battery Management, it is proposed to use a chip type bq29312A.

Full-fledged bq20z80 monitoring mechanisms allow you to accurately measure the key characteristics of the AB: Fig. 2 shows a general view of the functional diagram of the battery tracker, the software part of which is implemented on the chip bq29312A [9].

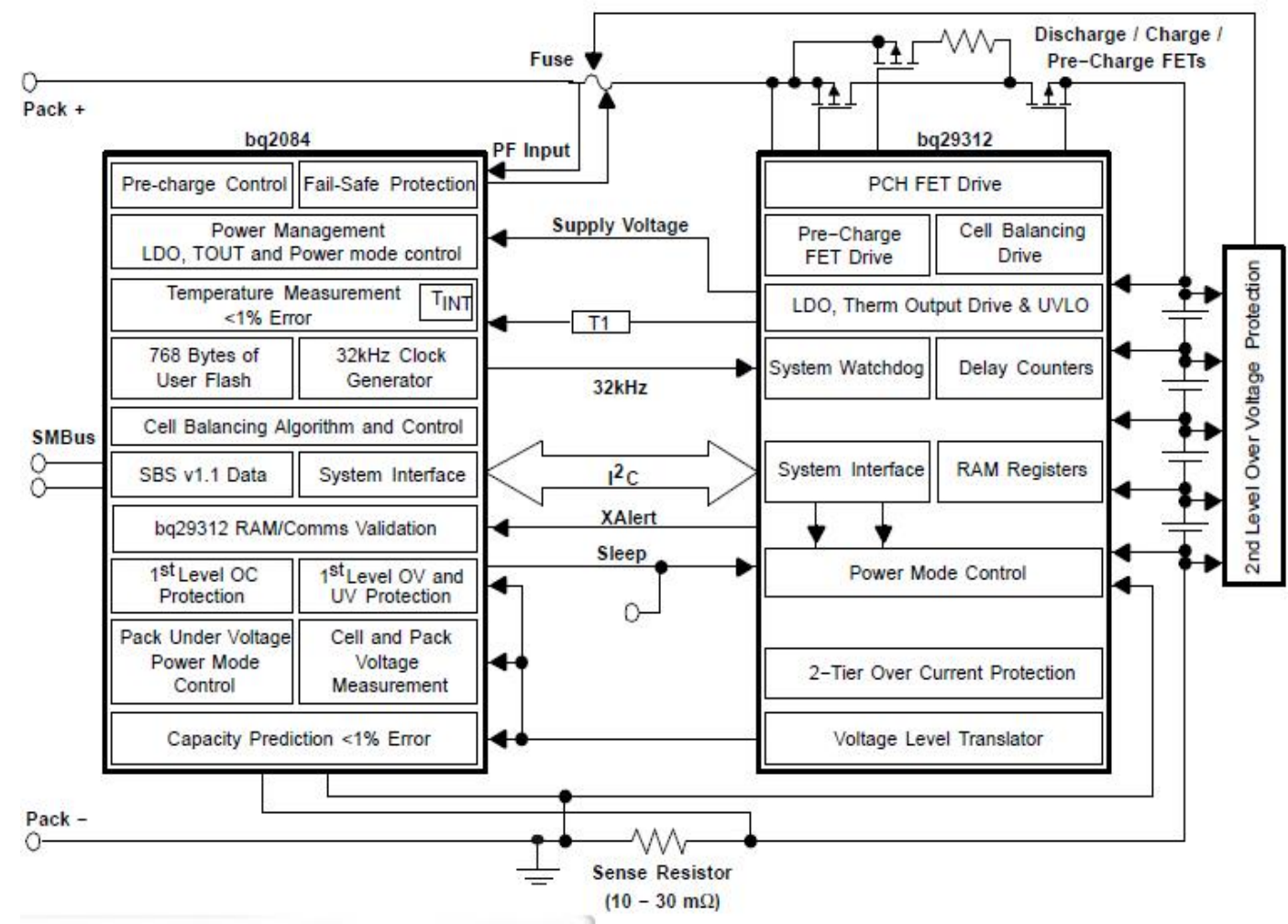

Fig. 2. General view of the functional circuit bq29312A

4. Projected schedule of maintenance during the GB life cycle of GB on their SOC and SOH according to the procedures of Battery Care and Battery Management. Monitoring the technical condition of batteries according to the procedure Battery Care and Battery Management provides an opportunity to optimize the schedule of maintenance GB $12 \mathrm{ST}-85 \mathrm{P}$ and move from the planned warning system maintenance to maintenance on demand with control parameters.

It is known that in order to provide electricity to all consumers of the tank, especially a reliable engine start, the operation of the fire control system, GB must have $75 \%$ of the remaining capacity in winter and $50 \%$ in summer, respectively. These values can be considered thresholds for deciding whether to recharge the battery. Thus, the use of the SOC battery tracker will allow us to conclude that it is necessary to recharge the battery. The time spent on measuring procedures for rechargeable batteries at the site is not reasonable, as a result of comparing data obtained at different times will determine in which batteries the degradation has just begun, and in which it has reached the level when they need to be replaced without waiting for fatal failure.

It is possible to decide on the need to replace the $\mathrm{GB}$ based on the results of $\mathrm{SOH}$ measurements. As mentioned above, the proper operation and quality and timely maintenance of batteries during their service life are necessary conditions for their trouble-free operation 
between maintenance and reduce the need for repair. Of course, a certain list of operations and three maintenance will remain unchanged for this type of GB - 12ST-85P are serviced lead-acid batteries. Such operations include the following:

- checking of reliability of fastening of tips of conductors with pole conclusions of batteries;

- checking of reliability of fastening of batteries on racks and in nests;

- checking the electrolyte level in all batteries; cleaning the surface of the batteries from dust and dirt, the contacts of the surface of the output terminals from oxide;

- checking the cleanliness of the vents in the plugs.

But the frequency of maintenance and control training cycle (CTC) can be optimized by using a battery tracker.

The following is a graph of the projected residual service life of the battery when monitoring the technical condition using the procedures Battery Care and Battery Management during its service life (Fig. 3).

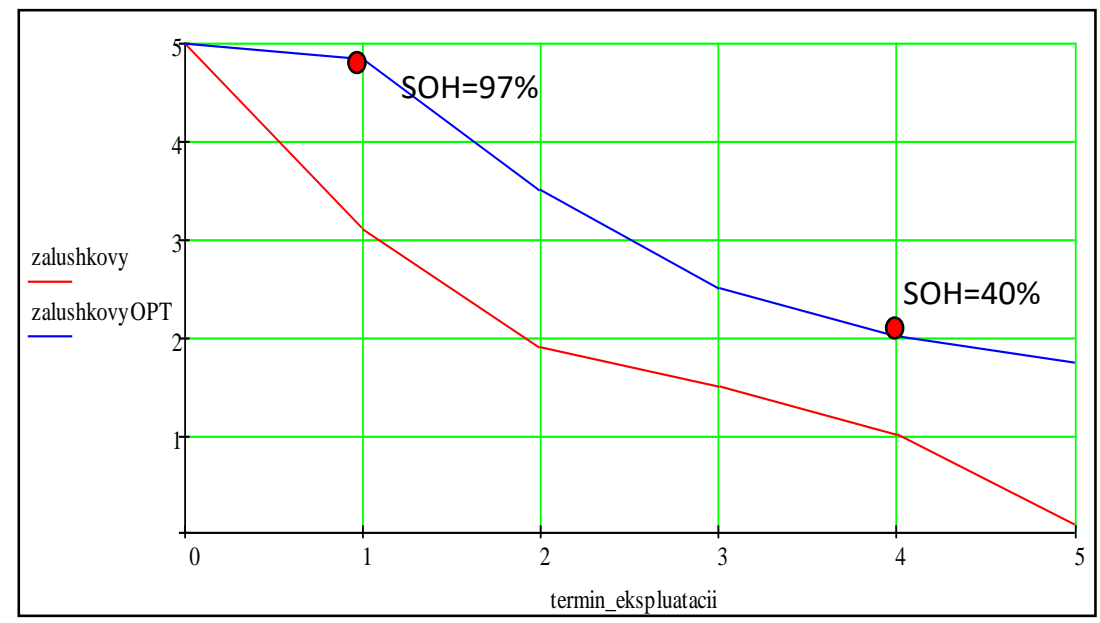

Fig. 3. Projected residual operational life of the battery during the monitoring of technical condition using Battery Care and Battery Management procedures during its service life

This figure compares the projected residual life of the battery during its service life without monitoring the technical condition using Battery Care and Battery Management procedures and with it. The graph also shows the moments of $\mathrm{SOH} \mathrm{AB}$ assessment during the MA-1 and MA-2 of the machine, in which certain operations were postponed, in particular the CTC.

In the absence of a real battery tracker, the estimate of $\mathrm{SOH}$ and $\mathrm{SOC} \mathrm{AB}$ was obtained according to the proposed method based on the results of measurements of battery parameters. The optimal service life is proposed in the expression:

$$
\text { zalyshkovy }^{\text {OPT }}=\text { zalyskovy } \cdot \mathrm{SOH}
$$

So, the application of Battery Care and Battery Management procedures during the life of the $\mathrm{AB}$ will allow. increase the period and reduce the volume of a certain number of operations during maintenance.

СПИСОК ЛІТЕРАТУРИ

1. Гумелёв В.Ю., Кочуров А.А. Факторы, влияющие на срок службы аккумуляторных батарей // Исследования в области естественных наук. 2013. № 5 [Электронный ресурс]. URL: http://science.snauka.ru/2013/05/4946

2. Юров Ю.Ю., Постников А.А., Гумелёв В.Ю. Краткая оценка методов диагностирования свинцово-кислотных аккумуляторных батарей. // Современная техника и технологии. - 2015. - № 12 [Электронный pecypc]. URL: http://technology.snauka.ru/2015/12/8775.

3. Кочуров А. А. Теоретические основы решения проблемы увеличения сроков службы аккумуляторных батарей при хранении и повышения эффективности способов их восстановления / А. А. Кочуров, Н. П. Шевченко, В. Ю. Гумелев. - Рязань: РВАИ, 2009 - 249 с.

4. Valve-Regulated Lead-Acid Batteries [Электронный pecypc] / Patrick T. Moseley, Jurgen Garche, C. D. Parker, D. A. J. Rand. - Amsterdam: Elsevier B. V., 2004. - URL: http://bookree.org/reader?file=676368\&pg=1.

5. Метод оперативной диагностики доступной емкости свинцовых аккумуляторов (батарей) / А. А. Алешкин и [др.] // Электрохимическая энергетика. - 2013. - № 1. - С.46-53.

6. Постников А.А., Юров Ю.Ю., Гумелёв В. Ю. Оценка и выбор параметров для контроля технического состояния аккумуляторных батарей / А.А. Постников // Научный резерв. - Рязанское высшее воздушно-десантное командное училище имени генерала армии В. Ф. Маргелова. - 2018. - № 1(1). - c.54-59.

7. Ольховіков С.В. Оцінка технічного стану хімічних джерел струму / С.В. Ольховіков // Системи обробки інформації: зб. наук. пр. - Х.: ХВУ, 2004. - Вип. 9. - С. 114-123.

8. Вайлов, А.М. Автоматизация контроля и обслуживания аккумуляторных батарей / А.М. Вайлов, Ф.И. Эйгель. - М.: Связь, 1985. - $156 \mathrm{c.}$

9. Simon Wen. Impedance TrackTM Gas Gauge for Novice, Application Report (SLUA375), [On-line]: Texas Instruments, Jan 2006: http://www.ti.com/lit/an/slua375/slua375.pdf

10. Lead-acid batteries: The growing need for monitoring state-of-charge and health. Electronic Products. Cambridge, MA URL: https://www.electronicproducts.com/lead-acid-batteries-the-growing-need-for-monitoring-state-of-charge-and-health/ 
11. Battery University, How to Measure State-of-Charge URL: http://batteryuniversity.com/learn/article/how_to_measure_state_of_charge/

12. Battery Council International, Lead Acid Batteries: http://batterycouncil.org/?page=Lead Acid Batteries

\title{
REFERENCES
}

1. Gumelev V. Yu. and Kochurov A. A. (2013) "Factors Affecting Battery Life" [On-line], Issledovaniya v oblasti yestestvennykh nauk, № 5 - URL: http://science.snauka.ru/2013/05/4946.

2. Yurov Yu.Yu., Postnikov A.A. and Gumelev V.Yu. (2015) [On-line], "Brief evaluation of methods for diagnosing lead-acid storage batteries.”, Sovremennaya tekhnika i tekhnologii, № 12, URL: http://technology.snauka.ru/2015/12/8775.

3. Kochurov, A. A. Shevchenko, N. P. and Gumelev V. Yu. (2009), Teoreticheskiye osnovy resheniya problemy uvelicheniya srokov sluzhby akkumulyatornykh batarey pri khranenii $i$ povysheniya effektivnosti sposobov ikh vosstanovleniya [Theoretical foundations for solving the problem of increasing the service life of storage batteries and improving the efficiency of methods for their recovery], RVAI, Ryazan', RU.

4. Patrick T. Moseley, Jurgen Garche, and C. D. Parker, D. A. J. Rand. (2004), [On-line] Valve-Regulated Lead-Acid Batteries, Amsterdam: Elsevier B. V., NL. - URL: http://bookree.org/reader?file $=676368 \& p g=1$.

5. Aleshkin A. A. (ed.) (2013), "Method of on-line diagnostics of the available capacity of lead-acid accumulators (batteries)", Elektrokhimicheskaya energetika, № 1, pp.46-53.

6. Postnikov A.A., Yurov Yu.Yu. and Gumelev V. Yu. (2018), "Evaluation and selection of parameters for monitoring the technical condition of batteries", Nauchnyy rezerv, № 1(1), pp. 54-59.

7. Ol'khovíkov, S.V. (2004), "Assessment of the technical condition of chemical current sources", Systemy obrobky informatsiyi: zb. nauk. pr., vol. 9, pp. 114-123.

8. Vaylov A.M. and Eygel'. F.I. '(1985), Avtomatizatsiya kontrolya i obsluzhivaniya akkumulyatornykh batarey [Battery control and maintenance automation], Svyaz, Moscow, SU.

9. Simon Wen. Impedance TrackTM Gas Gauge for Novice, Application Report (SLUA375), [On-line]: Texas Instruments, Jan 2006: http://www.ti.com/lit/an/slua375/slua375.pdf.

10. Lead-acid batteries: The growing need for monitoring state-of-charge and health. Electronic Products. Cambridge, MA. URL: https://www.electronicproducts.com/lead-acid-batteries-the-growing-need-for-monitoring-state-of-charge-and-health/

11. Battery University, How to Measure State-of-Charge URL: http://batteryuniversity.com/learn/article/how_to_measure_state_of_charge.

12. Battery Council International, Lead Acid Batteries [On-line]: http://batterycouncil.org/?page=Lead Acid Batteries.

Received (Надійшла) 15.09.2021

Accepted for publication (Прийнята до друку) 27.10.2021

\author{
Динамічний моніторинг технічного стану стартерних акумуляторних батарей \\ в процесі їх життєвого циклу згідно процедур battery care and battery management
}

О. А. Макогон, І. О. Славуцький, М. І. Чурбанов, О. П. Логвіненко, В. В. Іксариця, О. В. Аненкова

Анотація. Предметом вивчення статті є оцінка параметрів свинцево-кислотних акумуляторних батарей та термінів їх служби задля планування технічного обслуговування при експлуатації свинцево-кислотних акумуляторних батарей Метою дослідження $\epsilon$ розробка методики моніторингу технічного стану стартерних акумуляторних батарей в процесі їх життєвого циклу на основі використання сучасних інформаційних технологій. Завдання дослідження: Провести порівняльний аналіз процедур Battery Care and Battery Management та визначення технічного стану стартерних акумуляторних батарей, які використовуються на вітчизняній колісній та гусеничній техніці, та визначити ключові характеристики для моніторингу АБ в процесі їх життєвого циклу. Визначити методику діагностування АБ для здійснення динамічного моніторингу іiі технічного стану в процесі життєвого циклу згідно процедур догляду за акумулятором та управління ним. Визначити загальний вигляд функціональної схеми акумуляторного треккера програмно-апаратного приладу, здатного здійснювати догляд за акумулятором та управління ним. Надати пропозиції щодо підвищення ефективності технічного обслуговування акумуляторних батарей за допомогою акумуляторних треккерів. Методологічною основою дослідження стали загальнонаукові та спеціальні методи наукового пізнання. Отримані наступні результати: . За методикою, що пропонується, шляхом зіставлення отриманих в різний час даних нескладно визначити, в яких батареях деградація тільки почалася, а в яких досягла рівня, коли їх необхідно замінити, не чекаючи фатального збою. Моніторинг технічного стану акумуляторних батарей за допомогою акумуляторних треккерів, реалізуючих процедуру Battery Care and Battery Management надасть можливість оптимізувати графік проведення ТО АБ 12СТ- 85Р та перейти від планово-попереджувальної системи ТО до проведення ТО за вимогою 3 контролем параметрів. В цьому випадку можна збільшити період та зменшити обсяг проведення певної кількості операцій при проведенні ТО АБ. Висновки. В якості перспективного напряму розвитку експлуатації АБ можна вважати розробку акумуляторних треккірів - програмно-апаратних приладів, здатних здійснювати догляд за акумулятором та управління ним (Battery care and battery management). Правильний підбір АБ і зарядних пристроїв, кваліфікована експлуатація та своєчасній контроль залишкового ресурсу, є найголовнішим вимогою їх експлуатації. Тільки в цьому випадку, можливо, домогтися найбільшої економічної ефективності застосування АБ та продовження їх експлуатаційного ресурсу. Моніторинг технічного стану акумуляторних батарей за процедурою Battery Care and Battery Management надає можливість оптимізувати графік проведення ТО АБ 12СТ-85Р та перейти від плановопопереджувальної системи ТО до проведення ТО за вимогою з контролем параметрів. Таким чином можна збільшити період та зменшити обсяг проведення певної кількості операцій при проведенні ТО АБ.

Ключові слова: догляд за батареєю та управління батареєю, АБ-треккер, свинцево-кислотні акумулятори, обслуговування акумулятора $12 \mathrm{CT}-85 \mathrm{P}$. 